\title{
Asian Women's Body Construction in Online News Media
}

\author{
Daniel Susilo \\ Faculty of Communications Science \\ Dr. Soetomo University \\ Surabaya, Indonesia \\ daniel.susilo@unitomo.ac.id
}

\begin{abstract}
It would not be a become be a problematic issue if gender differences were did not create gender inequalities. However, it turns out that gender differences have created various injustices leading to inequality of opportunities, rights, and responsibilities, especially to for women. Those phenomena can be reflected and even reinforced by the online news media in line with their rapid growth. Hence, this research seeks to investigate the women's representation as rape victims in Indonesian online media from the feminist perspective of critical discourse analysis by Sara Mills. The data are taken from Tribunnews.com and analyzed by the qualitative content analysis. The results show that there is a tendency for gender inequality. This can be seen from the depiction of the victim as a weak, powerless, gentle, and subordinate to men.
\end{abstract}

Keywords-asian women; critical discourse analysis; gender inequality; online media

\section{INTRODUCTION}

In line with globalization issues, raising global awareness on gender equality toward sustainable development has become a major priority in Asia-Pacific after The 4th World Conference on Women held in Beijing in 1995 [1]. In support of the campaign, Indonesia has been persistently decreasing unfair opportunities due to unfavorable stereotyping and positioning gender issues as national policy, such as releasing Presidential Instruction No.9/2000 [2] and preparing a gender equality and justice bill. Through media, these long-established issues should have been promoted widely to improve gender responsiveness.

Unfortunately, the latest research, e.g. Wulandari [3], Hadiati [4], Afridah [5], Susilo [6], Susilo dan Haezer [7], Susilo [8] still confirms that journalism ethics are not still executed properly, as it is known that women are mostly the target of gender inequality. In fact, Wood [9] has already proposed for a long time that the media were likely to discredit women and favor the position of men instead, then expose women in stereotypical ways related to traditional views. Based on recent reports from the UNESCO and UNDP, the imbalance of the number of female journalists and male journalists, socio-cultural, institutional and political contexts of society are still dominant factors in this matter. As it is known, media are not the ones that created this issue, but their role is essential in resolving or even exacerbating the injustice to women [10]. Thus Hariyanto [11] and Edstrom [12] support that gender equality discourses by publishing objective news has not been performed yet by most of the media today.

\section{RESEARCH METHOD}

As illustrated from the reviews above, this study will conduct further research by analyzing the media construction of rape news within the framework of Sara Mills's CDA at the macro level. Mills [13] emphasizes how women are displayed in text based on the examination from the major components. They are subject and object as internal components of the text, with writer and reader as external components of the text. Here the particular issues can be investigated not only from the language use in the text itself, but also from the one who writes the text and the one who reads the text. Finally, the ideology that lies behind the depiction of the text can be revealed.

In this study, the focus is to expose the rape news taken from Tribunnews.com instead of analyzing the women's role in the domestic area like Suwasana [14] and Siswati research [15]. The curiosity appears of whether women as the victim are represented positively or negatively by the media. Beside the list of studies before, this study is expected to fill the previous research gap as well. On the other side, the selection of the news from Tribunnews.com is due to its well-known online media which has been constantly publishing the latest news and corporate to Kompas group. Then the data are analyzed by a qualitative content analysis technique that enables the media beliefs to be revealed. The technique is usually suitable for written types of communication, such as newspaper. A literature study is also added to strengthen the discussion of the study.

\section{RESULTS AND DISCUSSION}

The discussion of Sara Mills's CDA is divided into four major viewpoints. The data are described from each viewpoint presented in the table below to reveal how the rape news are presented by Tribunnews.com. Here is a brief summary of Sara Mills's CDA framework. 
TABLE I. BRIEF SUMMARY OF SARA MILLS'S CDA FRAMEWORK

\begin{tabular}{|l|l|l|}
\hline No & Position & \multicolumn{1}{c|}{ Things that should be described } \\
\hline 1 & $\begin{array}{l}\text { a. How is the person or event presented? } \\
\text { b. Who is the person or event viewed? } \\
\text { c. Who is the subject (person/ event) that tells } \\
\text { the story in the text? } \\
\text { Object } \\
\text { the Who is the object (person/event) that is told in } \\
\text { e. Is there any chance for social actors or groups } \\
\text { to present their presence or ideas to others? }\end{array}$ \\
\hline 2 & $\begin{array}{l}\text { a. How are the readers' positions displayed in the } \\
\text { text? } \\
\text { briter- How do the readers see themselves in the text? } \\
\text { c. Which groups do the readers identify } \\
\text { themselves with? }\end{array}$ \\
\hline
\end{tabular}

The 1st data is "Gara-gara Dendam, Pria Ini Nekat Renggut Kesucian Seorang Gadis" (Due to Resentment, This Man is Determined to Take a Girl's Purity). Then, the 2nd data is "Diancam Potong Payudara, Gadis Lahat Tak Berdaya Diperkosa Berulang Kali Pria Ini" (Threaten to Cut Her Breasts, A Powerless Girl in Lahat is Raped Repeatedly by the Man). Both of them were published on Wednesday, 4th October 2017. Here a brief finding and discussion of the data.

\section{A. Subject Position}

In the $1^{\text {st }}$ data, the analysis shows that the storyteller (subject) is Sutomo, who is the offender.

\section{Kepada wartawan, Sutomo mengaku hanya mencabuli} korban satu kali di rumahnya

To the reporter, Sutomo only confesses to raping the victim once

Taken from $4^{\text {th }}$ Line

As shown above, Sutomo is allowed to discuss himself and his actions from his own point of view. This makes Sutomo seem to be the narrator and the representation of the victim is displayed from his opinions. The same thing also happens in the 2nd data where the offender, Budi Harjo, is the storyteller of the text. This is exemplified in the following excerpt.

"Pas sampai dirumah kosong tersebut SW diajak menginap satu malam. Dan disaat itulah tersangka ini melakukan aksinya. Awalnya memeluk kemudian memaksa masuk dalam kamar hingga menyetubuhi korban," yang dilansir dari Tribunnews.com.

"After arriving at a vacant house, SW is invited to stay over a night. At the time, the offender does the action. Firstly, he hugs and forces her to go into room to rape her" quoted from Tribunnews.com

The action, its process, and its offender are known by the journalist from the offender (Sutomo, Budi Harjo). As expressed from their point of view, there is a tendency to marginalize the victim's position. The victims do not reveal the incidents and their presence appears in the text from their offender instead.

\section{B. Object Position}

In the $1^{\text {st }}$ data, the analysis shows that the person that is told (object) in the text is the underage victim. The sequence of incidents is revealed from the offender, Sutomo. It is exemplified in the following excerpt.

Modusnya, Sutomo mengiming-imingi korban dengan mainan, lalu mengajaknya ke rumah pelaku. Sesampai di rumah Sutomo, korban pun dicabuli. "Gun sekalian. Guleh dendam ke ibuen (Hanya sekali. Saya dendam pada ibunya)," kata Sutomo dengan Bahasa Madura di Mapolres Probolinggo, Rabu (4/10/2017).

Sutomo's trick is to lure the victim with toys, then take her to his house. Arriving at his house, the victim is sexually abused. "Only once. I have a grudge against her mother," said Sutomo with Madurese language at Probolinggo Police Headquarters on Wednesday (4/10/2017).

$5^{\text {th }}, 6^{\text {th }}, 7^{\text {th }}$ Lines

In the $2^{\text {nd }}$ data, $\mathrm{SW}$ is positioned as the object as well as the victim of the violence. The incident is also explained from the point of view of her offender, Budi Harjo. Her position as an object makes her not get a chance to tell the story from her own perspective. This can be exemplified in the following excerpt.

Awalnya, diterangkannya SW sempat menolak dan memberontak. Budi tak menyerah begitu saja. Budi nekat ancam korban. Budi akan mencekik korban dan memotong payudara korban jika tidak mau melayani nafsu bringasnya.

Initially, he explained that SW had refused and rebelled. Budi did not give up so easily. Budi recklessly threatened the victim. Budi would strangle the victim and cut off her breast if they do not want to serve him.

Taken from $17^{\text {th }}, 18^{\text {th }}, 19^{\text {th }}, 20^{\text {th }}$ Lines

\section{News Writer Position}

Based on both data, the writer's choice of the news title can reveal their priority of the text. Indeed, it shows that the writers position themselves as men because they tend to be permissive toward the offender's action. The writer seems to justify the offender's action due to his revenge reason. The writer should have presented an unbiased perspective because no matter whatever the reasons are, that action cannot ever be accepted. In addition, both of the titles reinforce the assumption that the writers tend to treat the offender in different way.

\section{Reader's Position}

Reader positioning is a cooperation between the news writers and the readers. The media contributes to shaping the reader positioning, which is the readers' attitude and feeling. In other words, there is a transmitting process about the media's values and ideas. On the other side, the personal factors that come from the readers such as their knowledge of the text or their socio-cultural background affect how they make an interpretation.

Based on the analysis of data, the results show that when the sources of data come from an offender's perspectives as the actor of the event, the readers seem to be positioned as actors 
as well. The texts tend to contain the news writer's point of view as men. Due to such positioning, the media is able to persuade the readers to have the same position as the media. At the same time, as known that Indonesian socio-culture is still dominated by patriarchal ideology, which greatly affects the unequal women representation. In the end, the cooperation between news writers and readers is to preserve the existing gender bias in society.

Those reviews are meanings are not coming from the analysis of language use, but also from the writer who creates the text and the reader who interprets the text. The texts are produced through an active and dynamic process. The readers and texts share the same meaning in producing text meanings. That relationship places a person as a part of their relationship with the larger system of values in which they live in society. At this point, ideology works. The texts degrade or marginalize the position of women, representing the patriarchal ideology that exist in society. This means that the patriarchy culture plays a role in forming a patriarchal text as well. This patriarchal ideology is dispersed and embedded in the workplace of journalists (the media redaction division), starting from the interviewing process by the reporter, then the producing and editing of the text. Thus, the output of the news will tend to follow the standards and tastes of men.

As illustrated above, it can be concluded that Tribunnews.com has an indication of gender bias in describing the rape victims. In digging for information, the news writers tend to put forward the position as a male because the resource of the information is from the sex offender. Thus, the published news contains gender inequality. In the end, the news made by the media depicts the position of the offender as the subject while the female position is the opposite. The information should be emphasizing the victim more and from the perspective of the victim.

In addition, Tribunnews.com illustrates the victim as a "girl". According to KBBI Online, a girl is described as "unmarried woman or virgin". Moreover, the media describes the victim in detail regarding her personal information, which is actually disadvantageous to the victim. It is similar to Susilo argument that the women's image is as an "object" to satisfy men. Then, it is reinforced by Susilo who state that online news seeks to provide fantasy satisfaction and the image of sexuality to the readers of news of rape [7]. Without realizing, women have been socially constructed to be in a marginal world, namely the world of objects. In addition, depictions presented by the Tribunnews.com are that women are weak, powerless, gentle, and subordinate to men.

\section{CONCLUSION}

Based on the analysis data and literature studies, the role of media in reporting the case tends to be gender biased. This is shown by the placement of women, which are described as weak, helpless, easily persuaded and subordinate to men. The journalists as news writers in the Indonesian context still perpetuate the patriarchy by describing the sex offender as the subject of the narrator in every rape case. The characteristics of the rape texts themselves tend to take information from the offender's perspective, so the coverage is unbalanced. Thus, the readers will position themselves on the side of the sex offender. Thus, the position of women which are previously quite marginalized in a socio-cultural perspective (patriarchy) are increasingly represented poorly by the media. However, Susilo [7] reveals that most people have realized that the performance of media is still poor in accelerating gender equality. Regardless, the readers' critical thinking ability should be improved in order to not be manipulated by the media. Hopefully, the result of this study can remind the press council to take significant action in order to deliver objective news for people.

\section{ACKNOWLEDGMENT}

The author would to express his gratitude to Dean of Faculty Communications Science, Dr. Soetomo University for his support to this research.

\section{REFERENCES}

[1] "Asian and Pacific ministerial declaration on advancing gender equality and women's empowerment," Report of the Asian and Pacific Conference on Gender Equality and Women's Empowerment, pp. 4-36, Dec. 2015.

[2] R.B. Doloksaribu, Women and Girls' Education and Gender Equality in Basic Education in Indonesia. In ESCAP (ed.), Putting Gender Mainstreaming into Practice, United Nations, New York, pp 119., 2003

[3] D. Wulandari, "Konstruksi pemberitaan politik ber-isu gender," INTERAKSI: Jurnal Ilmu Komunikasi, vol 1 no 1. 2015.

[4] E. Hadiati., I. Abdullah and W. Udasmoro, "Konstruksi media terhadap pemberitaan kasus perempuan koruptor," Jurnal Al-Ulum, vol. 13 no. 2, pp 345-372., 2013.

[5] Afridah, "Pelanggaran kode etik jurnalistik pada pemberitaan kekerasan seksual terhadap perempuan di 'lampu hijau'." Jurnal Kriminologi Indonesia, vol. 10 no. 1, pp 1-8, 2014.

[6] D. Susilo, "Jurnalisme Tidak Peka Gender: Studi Analisis Wacana Pemberitaan Perempuan oleh Media Online Tribunnews.com”. In R. Ida (Ed). Prosiding Post-Graduate Roundtable Universitas Airlangga Surabaya 2014, 6 Desember 2014: pp 17-25. 2014.

[7] D. Susilo and E. Haezer, "Konstruksi seksualitas perempuan dalam berita pemerkosaan di teks media daring”, Jurnal Kawistara Vol 7 No 1, April 2017.

[8] D. Susilo, "Masculinity discourse on media text: A critical review about news about violence on online news portals," Masyarakat, Kebudayaan dan Politik, vol. 30, no. 4, p. 344, Dec. 2017.

[9] J. Wood, Gendered Media: The Influence of Media on Views of Gender, Gendered Lives: Communication, Gender, and Culture, 231-244.

[10] “Asian and Pacific ministerial declaration on advancing gender equality and women's empowerment," Report of the Asian and Pacific Conference on Gender Equality and Women's Empowerment, pp. 4-36, Dec. 2015.

[11] E. Hariyanto, "Gender dalam konstruksi media". KOMUNIKA, vol 3 no 2, pp 167-183, 2009.

[12] M. Edstrom, "The role of the internet and new meedia: amplifier of gender inequalities or vehicle for change?'In F. Bettio and S. Sansonetti (eds.) Visions for Gender Equality, European Commission Directorate General for Justice, pp 87-106, 2015.

[13] S. Mills, "Stylistics, Feminist," Encyclopedia of Language \& Linguistics, pp. 221-223, 2006.

[14] A.A. Suwasana. "Perspektif Gender dalam Representasi Iklan' Nirmana, vol 3 no 2, 2004.

[15] E. Siswati, "Representasi domestikasi perempuan dalam iklan,” Jurnal Ilmu Komunikasi, vol. 11, no. 2, Jan. 2015. 